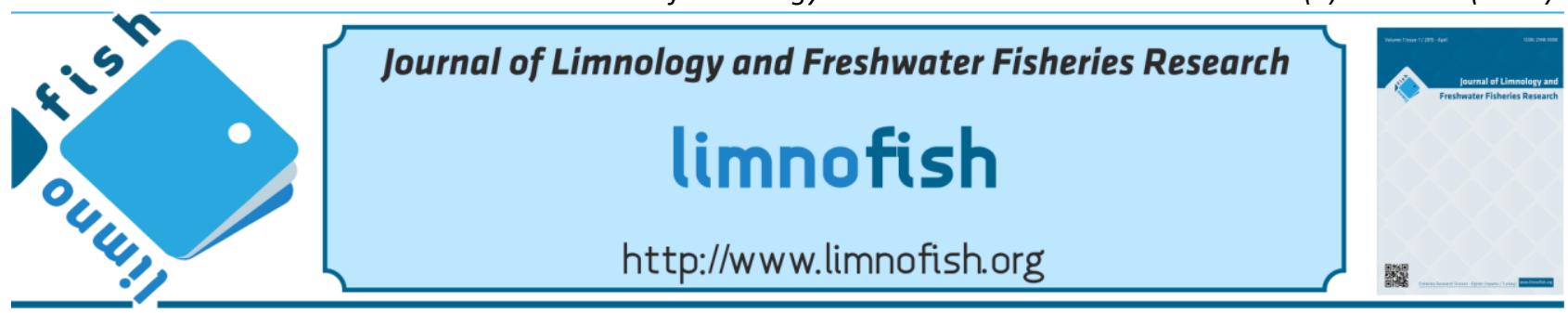

\title{
Isolation and Identification of Streptococcus parauberis From Freshwater Fish in Turkey
}

\author{
Zübeyde HANOL BEKTAŞ ${ }^{*}$ (D) Füsun B. UÇAR ${ }^{2}$ iD , Soner SAVAŞER ${ }^{1}$ \\ ${ }^{1}$ Fisheries Research Institute Eğirdir, Isparta, Turkey \\ ${ }^{2}$ Ege University' Faculty of Science, Department of Biology, Bornova, İzmir, Turkey
}

\section{A B STRACT}

Streptococcus parauberis is an alpha-hemolytic gram positive coccoid bacterium belonging to the Streptococcaceae family. This bacterium cause streptococcosis is a major disease in cultured fish due to the intensification of aquaculture and causes significant economic losses in fish farm industry. In our study, we isolated a total of 37 lactic acid bacteria from wild fish (Sander lucioperca, Carassius gibelio, Cyprinus carpio) of Lake Eğirdir and cultured fish (Oncorhynchus mykiss, Walbaum) of farm in Turkey. For the isolation of bacteria phenotypic and biochemical characteristics of the 37 isolates obtained from the colonies grown on MRS, TSA and M17 agar characterized by determining colony morphology, cell morphology, motility, gram staining and the production of cytochrome oxidase and catalase. Further biochemical characteristics were determined using conventional tests according to Bergey's Manual of Systematic Bacteriology. From the isolated lactic acid bacteria 25 of were identified as $S$. parauberis, 2 of as Vagococcus sp., 2 of as Lactococcus garvieae and 5 of as Lactococcus lactis by culture-based, biochemical test and 16Sr RNA gene sequencing techniques but 3 of them couldn't (F65, F49 and F50) identified. In this study, the main objective of us is to identify $S$. parauberis with conventional and 16Sr RNA gene sequencing techniques from wild fish in Lake Eğirdir and in cultured fish in fish farm of Egirdir-Turkey.

Keywords: 16Sr RNA, freshwater, molecular identification, fish disease, aquaculture.

\section{ARTICLE INFO}

\section{RESEARCH ARTICLE}

$\begin{array}{lll}\text { Received } & : 21.08 .2017 \\ \text { Revised } & : 15.11 .2017 \\ \text { Accepted } & : 22.11 .2017 \\ \text { Published } & : 29.12 .2017\end{array}$

DOI: $10.17216 /$ LimnoFish.335516

* CORRESPONDING AUTHOR

zubeydehanol17@gmail.com Tel : +902463133460

\section{Streptococcus parauberis'in Türkiye'deki Tatlısu Balıklarından İzolasyon ve İdentifikasyonu}

Öz: Streptococcus parauberis alfa hemolitik, gram pozitif kokoid bir bakteri olup Streptococcaceae familyasına aittir. Bu bakteri kültür balıklarında yoğun üretimden kaynaklı çok önemli bir hastalık olan streptokokozise neden olmaktadır ve balık çiftliği endüstrisinde önemli bir ekonomik kayba neden olmaktadır. Çalışmamızda Eğirdir gölü balıklarından (Sander lucioperca, Carassius gibelio, Cyprinus carpio) ve kültür balığı türü olan (Oncorhynchus mykiss, Walbaum)'dan 37 tane laktik asit bakterisi izole edilmiştir. Laktik asit bakterilerinin tanımlanması için MRS, TSA ve M17 agardan izole edilen 37 izolatın fenotipik ve morfolojik karakterleri koloni morfolojisi, hücre morfolojisi, hareketlilik, gram boyama, katalaz ve oksidaz üretimiyle yapılmıştır. Diğer biyokimyasal özellikler de Bergey's Manual of Systematic Bacteriology’e göre yapılmıştır. İzole edilen bakterilerinden 25 tanesi S. parauberis, 2 tanesi Vagococcus sp., 2 tanesi Lactococcus garvieae ve 5 tanesi de Lactococcus lactis olarak biyokimyasal yöntemler ve 16Sr RNA gen sekansıyla tanımlanmıştır fakat 3 tanesi (F65, F49 ve F50) tanımlanamamıştır. Çalışmamızda $S$. parauberis'in izolasyon ve identifikasyonu ilk olarak Türkiye'deki Eğirdir gölü balıklarından ve gökkuşağı alabalığından gerçekleştirildi.

Anahtar kelimeler: 16Sr RNA, Tatlısu, moleküler tanımlama, balık hastalığı, yetiştiricilik.

How to Cite

Hanol Bektaş Z, Uçar FB, Savaşer S. 2017. Isolation and Identification of Streptococcus parauberis from Freshwater Fish in Turkey. LimnoFish. 3(3): 175-182. doi:10.17216/LimnoFish.335516

\section{Introduction}

Aquaculture has become an economically important industry in the world which requires continued research with scientific and technical developments and innovation. So the purpose of global aquaculture is to maximize the efficiency of 
production. The world aquaculture production in 2014 was approximately of 73.8 million tons, which represents around $41 \%$ of that obtained from extensive captures for human consumption. To meet the increased need of food in the World, there is an intensive production in fisheries and this makes inevitable the occurence of diseases (FAO 2016; Bondad-Reantaso et al. 2005; Kesarcodi-Watson et al. 2008; Subasinghe et al. 2009).

The appearance and development of a fish disease is the result of the interaction among pathogen, host and environment. It is important to point out that diseases classically considered as typical of freshwater aquaculture, such as furunculosis (Aeromonas salmonicida), bacterial kidney disease (BKD) (Renibacterium salmoninarum) and some types of streptococcosis are today important problems. Streptococcal infection is a disease affecting most of fish including wild and cultured fish (Toranzo et al. 2005).

The important fish pathogens which have importance are Lactococcus garvieae (synonym Enterococcus seriolicida), Lactococccus piscium, $S$. iniae (syn. S. shiloi), S. agalactiae (syn. S. difficile), Streptococcus parauberis and Vagococcus salmoninarum. Therefore, streptococcosis of fish should be regarded as a complex of similar diseases caused by different genera and species capable of inducing a central nervous damage characterised by suppurative exophthalmia and meningoencephalitis. While warm water streptococcosis (causing mortalities at temperatures above $15^{\circ} \mathrm{C}$ ) typically involves $L$. garvieae, S. iniae, S. agalactiae and $S$. parauberis, cold water streptococcosis (occurring at temperatures below $15{ }^{\circ} \mathrm{C}$ ) is caused by $L$. piscium and $V$. salmoninarum. It is important to report that the etiological agents of warm water streptococcosis are considered also as potential zoonotic agents capable to cause disease in humans (Domenech et al. 1996).

Streptococcus is a genus of bacteria containing some species that cause serious diseases in a number of different hosts. This disease causes significant economic losses in the aquaculture industry in the United States of America, Japan, Israel, South Africa, Iran, Australia, Philippines, Taiwan, Bahrain, Turkey and other countries. Streptococcal disease in fish was first reported in 1957 (Hoshina et al. 1958; Baeck et al. 2006; Rahimi and Yadollah 2013).

$S$. parauberis seems to be endemic of cultured turbot (Toranzo et al. 1994). S. parauberis was first identified as a fish pathogen after an outbreak in 1993 in cultured turbot (Scophthalmus maximus) in Spain (Domenech et al. 1996). It was also responsible for streptococcosis in olive flounder (Paralichthys olivaceus) from a fish farm on Jeju Island, Korea during 2005 (Baeck et al. 2006). Prior to these reports, S. parauberis was known primarily as an etiologic agent of mastitis in dairy cows (Williams and Collins 1990).

To date, examples of Streptococcus species that have been associated with disease in fish include: $S$. iniae, S. agalactiae, S. parauberis, S. dysgalactiae, $S$. faecium, S. milleri, S. uberis, S. ictaluri, S. phocae and S. faecalis (Yang and Li 2009).

Unfortunately, conventional biochemical tests do not allow for the precise identification and classification of streptococcal isolates, because of differences in growth rates, inoculum levels, and incubation periods (Facklam and Elliott 1995). Consequently, the number and the nature of bacteria species associated with fish streptococcosis remains controversial (Romalde JL et al. 2008).

Molecular techniques to diagnose fish streptococcosis are powerful method have been applied. The techniques based on amplification of 16S rRNA (Zlotkin et al. 1998a,1998b; Nho et al. 2009; Lämmler 1998) seem to be of choice as a standard method for diagnosis of these gram positive cocci. In the case of $S$. parauberis, detection can be performed using the procedures that described for mammals by Lämmler et al. (1998) which combines PCR amplification and endonuclease restriction. Here we report $S$. parauberis from freshwater fish and Rainbow trout (Oncorhychus mykiss, Walbaum) which are important economically. Especially, rainbow trout faced with diseases due to the intensive production and culture condition. For hindered of these diseases the one of the natural solution is probiotic bacteria. During the bacterial detection for probiotic bacteria $S$. parauberis obtained in significant densities by biochemical methods. Molecular techniques to diagnose fish streptococcosis are powerful method have been applied. The techniques based on amplification of 16Sr RNA seem to be of choice as a standard method for diagnosis of these gram positive cocci. So we made the identification of these bacteria by $16 \mathrm{Sr}$ RNA gene sequence analysis. Because the fast and correct identification is very important in fish farm for hindered and transport of disease from one fish to another. In this study, the main objective of us is to identify S. parauberis with conventional and $16 \mathrm{Sr}$ RNA gene sequencing techniques in wild fish in Lake Eğirdir and in cultured fish in fish farm of EgirdirTurkey.

\section{Material and Methods \\ Isolation of bacteria}

Gut and spleen samples obtained from healthy rainbow trout (O. mykiss) in fish farm during summer in Isparta province, and gut and spleen samples of carp (Cyprinus carpio), silver crucian carp 
(Carassius gibelio) and sander (Sander lucioperca) living in Egirdir lake were diluted for the isolation of lactic acid bacteria. Isolation sources and incubation conditions of bacterial isolates were given in Table 1 . The isolates were inoculated in the selective mediums. All the fish were treated in 1 liter of water containing $0.5 \mathrm{ml}$ phenoxyethanol for $2 \mathrm{~min}$ and killed. After one gram of sample obtained from the fish gut was placed in $10 \mathrm{ml}$ PBS (phosphate- buffered saline) and was diluted $10^{-7}$ times, $0.1 \mathrm{ml}$ dilutions were seeded on TSA (Tryptic Soy AgarMerck 1.05458), MRS (De Man, Ragosa and Sharpe Agar- Merck 1.10660) and M17 (Merck 1.15108) agar and incubated at $22{ }^{\circ} \mathrm{C}$ under aerobic and anaerobic conditions for 24-48 hours. Then those whose morphologies resembling lactic acid bacteria were selected from petri dishes and stocked in $15 \%$ of TSA at $-80^{\circ} \mathrm{C}$ (Perez-Sanchez et al. 2011).

Table 1. Isolation sources and incubation conditions of bacterial isolates

\begin{tabular}{|c|c|c|c|c|c|c|}
\hline Strain No & Fish & Organ & Medium & Aerobic/Anaerobic & Temperature & Incubation time \\
\hline 51 & C. gibelio & Gut & MRS & Aerobic/Anaerobic & $22^{\circ} \mathrm{C}$ & $24-48 h$ \\
\hline 34 & Trout & Spleen & M17 & Aerobic/Anaerobic & $22^{\circ} \mathrm{C}$ & $24-48 h$ \\
\hline 57 & C. gibelio & Gut & M17 & Aerobic/Anaerobic & $22^{\circ} \mathrm{C}$ & $24-48 h$ \\
\hline 35 & O. mykiss & Spleen & M17 & Aerobic/Anaerobic & $22^{\circ} \mathrm{C}$ & $24-48 h$ \\
\hline 61 & C. carpio & Gut & M17 & Aerobic/Anaerobic & $22^{\circ} \mathrm{C}$ & $24-48 h$ \\
\hline 56 & C. gibelio & Gut & M17 & Aerobic/Anaerobic & $22^{\circ} \mathrm{C}$ & $24-48 h$ \\
\hline 73 & C. gibelio & Gut & MRS & Aerobic/Anaerobic & $22^{\circ} \mathrm{C}$ & $24-48 h$ \\
\hline 42 & C. gibelio & Gut & TSA & Aerobic/Anaerobic & $22^{\circ} \mathrm{C}$ & $24-48 h$ \\
\hline 28 & C. carpio & Gut & $\mathrm{TSA}$ & Aerobic/Anaerobic & $22^{\circ} \mathrm{C}$ & $24-48 h$ \\
\hline 23 & C. gibelio & Gut & TSA & Aerobic/Anaerobic & $22^{\circ} \mathrm{C}$ & $24-48 h$ \\
\hline 48 & C. gibelio & Gut & MRS & Aerobic/Anaerobic & $22^{\circ} \mathrm{C}$ & $24-48 h$ \\
\hline 52 & C. gibelio & Gut & TSA & Aerobic/Anaerobic & $22^{\circ} \mathrm{C}$ & $24-48 h$ \\
\hline 41 & C. gibelio & Gut & TSA & Aerobic/Anaerobic & $22^{\circ} \mathrm{C}$ & $24-48 h$ \\
\hline 46 & C. gibelio & Gut & TSA & Aerobic/Anaerobic & $22^{\circ} \mathrm{C}$ & $24-48 h$ \\
\hline 43 & C. gibelio & Gut & TSA & Aerobic/Anaerobic & $22^{\circ} \mathrm{C}$ & $24-48 h$ \\
\hline 64 & S. lucioperca & Gut & M17 & Aerobic/Anaerobic & $22^{\circ} \mathrm{C}$ & $24-48 h$ \\
\hline 26 & S. lucioperca & Gut & M17 & Aerobic/Anaerobic & $22^{\circ} \mathrm{C}$ & $24-48 h$ \\
\hline 22 & C. gibelio & Gut & TSA & Aerobic/Anaerobic & $22^{\circ} \mathrm{C}$ & $24-48 h$ \\
\hline 58 & C. gibelio & Gut & M17 & Aerobic/Anaerobic & $22^{\circ} \mathrm{C}$ & $24-48 h$ \\
\hline 62 & C. carpio & Gut & M17 & Aerobic/Anaerobic & $22^{\circ} \mathrm{C}$ & $24-48 h$ \\
\hline 59 & C. gibelio & Spleen & M17 & Aerobic/Anaerobic & $22^{\circ} \mathrm{C}$ & $24-48 h$ \\
\hline 47 & C. gibelio & Gut & M17 & Aerobic/Anaerobic & $22^{\circ} \mathrm{C}$ & $24-48 h$ \\
\hline 44 & C. gibelio & Gut & M17 & Aerobic/Anaerobic & $22^{\circ} \mathrm{C}$ & $24-48 h$ \\
\hline 45 & C. gibelio & Gut & M17 & Aerobic/Anaerobic & $22^{\circ} \mathrm{C}$ & $24-48 h$ \\
\hline 63 & C. carpio & Gut & M17 & Aerobic/Anaerobic & $22^{\circ} \mathrm{C}$ & $24-48 h$ \\
\hline 19 & C. carpio & Gut & M17 & Aerobic/Anaerobic & $22^{\circ} \mathrm{C}$ & $24-48 h$ \\
\hline 18 & C. carpio & Gut & M17 & Aerobic/Anaerobic & $22^{\circ} \mathrm{C}$ & $24-48 h$ \\
\hline 25 & C. gibelio & Gut & M17 & Aerobic/Anaerobic & $22^{\circ} \mathrm{C}$ & $24-48 h$ \\
\hline 24 & C. gibelio & Gut & M17 & Aerobic/Anaerobic & $22^{\circ} \mathrm{C}$ & $24-48 h$ \\
\hline 60 & C. gibelio & Gut & M17 & Aerobic/Anaerobic & $22^{\circ} \mathrm{C}$ & $24-48 h$ \\
\hline 31 & C. gibelio & Gut & M17 & Aerobic/Anaerobic & $22^{\circ} \mathrm{C}$ & $24-48 h$ \\
\hline 55 & C. gibelio & Gut & M17 & Aerobic/Anaerobic & $22^{\circ} \mathrm{C}$ & $24-48 h$ \\
\hline 32 & C. gibelio & Gut & M17 & Aerobic/Anaerobic & $22^{\circ} \mathrm{C}$ & $24-48 h$ \\
\hline 29 & C. gibelio & Gut & M17 & Aerobic/Anaerobic & $22^{\circ} \mathrm{C}$ & $24-48 h$ \\
\hline
\end{tabular}

Biochemical and phenotypic characterization

Phenotypic and biochemical characteristics of the 37 isolates obtained from the colonies grown on MRS, TSA and M17 agar characterized by determining colony morphology, cell morphology, motility, gram staining (Figure 1) and the production of cytochrome oxidase and catalase. Further biochemical characteristics were determined using 
conventional tests according to Bergey's Manual of Systematic Bacteriology (Schleifer 1986).

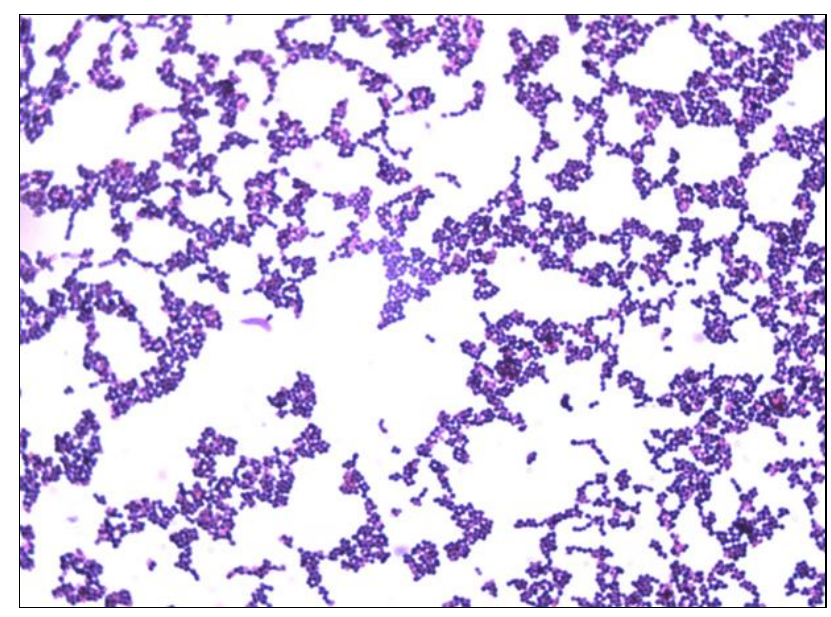

Figure 1. Gram staining of $S$. parauberis (F34) cultured on trypticase soy agar at $22^{\circ} \mathrm{C}$ for $24 \mathrm{~h}$.

\section{DNA isolation and molecular identification}

DNA isolation was carried out with the rapid phylogenetic analysis (Liu 2000). For the molecular biological identification 16Sr RNA about $1.5 \mathrm{~kb}$ regions of the 37 isolates were amplified with $27 \mathrm{~F}$ (5'-AGAGTTTGATCCTGGCTCAG-3') and 1492R (5'-GGTTACCTTGTTACGACTT-3') primers (216bp of 16S rRNA) using ARDRA PCR (Soto 2010). Representative amplification products of isolates were given in Figure 2.

\section{Sequencing}

The isolates were sequenced with the same primers used in PCR. The obtained sequence data were compared with the sequences in the GenBank database using the BLAST algorithm and then sent to NCBI (National Center for Biotechnology Information) to receive an access number.

\section{Antimicrobial susceptibility testing}

Antimicrobial susceptibility testing of $S$. parauberis isolates was performed with the disc diffusion method in accordance with guidelines for the Clinical and Laboratory Standards Institute (CLSI), and the following antibiotics (Oxoid) were tested with the disk diffusion method: doxcycline (30 $\mu \mathrm{g})$, enoxacine $(10 \mu \mathrm{g})$, erythromycin $(15 \mu \mathrm{g})$, florfenicol $(30 \mu \mathrm{g})$, trimethoprim/sulfamethoxazole $(1.25 / 23.75 \mu \mathrm{g})$, enrofloxacin $(5 \mu \mathrm{g})$, oxytetracycline $(30 \mu \mathrm{g})$, chloramphenicol $(30 \mu \mathrm{g})$, vancomycin $(30$ $\mu \mathrm{g})$, penicillin $(10 \mu \mathrm{g})$. Antimicrobial susceptibility test of isolates were given in Table 2.

\section{Experimental infection}

For experimental infection the method by Haines et al. (2013) used after a minor modification. Pathogenicity test of isolates was conducted using healthy rainbow trout $(9-10 \mathrm{~g})$. To determine if
S. parauberis (F34 and $\mathrm{F} 35)$ isolates from fish would produce infection in rainbow trout, a group of 20 fish ( $n=10 /$ tank $)$ was inoculated intraperitoneally with $1 \times 10^{5}$ bacteria by optical density in a final volume of $10 \mathrm{ul}$ sterile PBS for each isolate. Animals were held in 2 (PVC $\pi 150 \mathrm{~cm}=880$ L) maintained at $16{ }^{\circ} \mathrm{C}$, supplied with freshwater and aeration and monitored daily for clinical signs of streptococcosis for two weeks, including evidence of external hemorrhage, exophthalmia, lethargy, and loss of appetite. Two weeks after inoculation all fish were euthanized and the spleens were aseptically removed (Figure 3) macerated and suspended in liquid media for re-isolation as described above. After experimental infection agent of disease ( $S$. parauberis) was obtained from kidney of fish that have signs of streptococcosis and from the results of bacterial examination made with API 20 strep test S.parauberis reisolated from diseased fish.

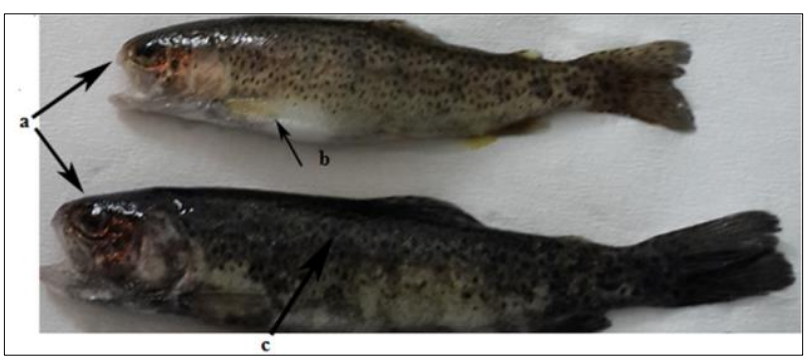

Figure 2. Rainbow trout (O. mykiss) showing clinical signs of streptococcosis a) Exopthalmus and haemorrhagic eyes, b) ascites, c) dark skin

\section{Results}

Upon the completion of the phenotypic tests, it was found that 25 of the 37 isolates belonged to the genus Streptococcus, 5 of them belonged to the genus Lactococcus and 2 of them belonged to the genus Vagococcus. After being amplified with universal primers definitive identification was made by sequence analysis. However, after the sequence analysis, while 34 of these 37 strains were identified, 3 were not (F65, F49 and F50). The identified 34 isolates with accession number obtained from genebank like as follows: F51 (Accession number KP137338), F34 ( KP137328), F57 (KP137342), F35 (KP137329), F61 (KP137346), F56 (KP137341), F73 (KP137350), F42 (KP137331), F28 (KP137324), F23 (KP137320), F48 (KP137337), F52 (KP137339), F41 (KP137330), F46 (KP137335), F43 (KP137332), F64 (KP137349), F26 (KP137323), F22 (KP137319), F58 (KP137343), F62 (KP137347), F59 (KP137344), F47 (KP137336), F44 (KP137333), F45 (KP137334), F63 (KP137348) were identified as $S$. parauberis, F18 (KP137317), F19 (KP13731) as $L$. 
garvieae, F24 (KP137321), F25 (KP137322) as Vagococcus sp. F60 (KP137345), F55 (KP137340), F29 (KP137325),F31 (KP137326),F32 (KP137327) as L. lactis subsp lactis.

Isolation sources and incubation conditions of bacterial isolates were given in Table 1 . Bacteria isolated from fish were gram positive ovoid cells forming chains or single cells (Figure1) growth occured from $4^{\circ} \mathrm{C}$ (except F34, F35 and F73) to $45^{\circ} \mathrm{C}$ (except F23 and F48) with 0 to $6.5 \%$ (except F24, F23, F48, F47, F22) NaCl. Antibiotic susceptibility test results are given in Table 2. Of the samples studied, except F18, F19, F26, F22 and F29 all isolates were sensitive to all antibiotics tested. Three isolates were multiple resistant against to 3 antibiotics which are F18 (en, o, c), F19 (en, o, c), F26 (do, sxt, c) respectively. The highest antibiotic resistance was to enoxacin, oxytetracycline and chloramphenicol. All the strains were sensitive to vancomycin and penicillin (except F29). In pathogenecity test, after inoculation with
S. parauberis the $90-100 \%$ of the fish species were died in two weeks.

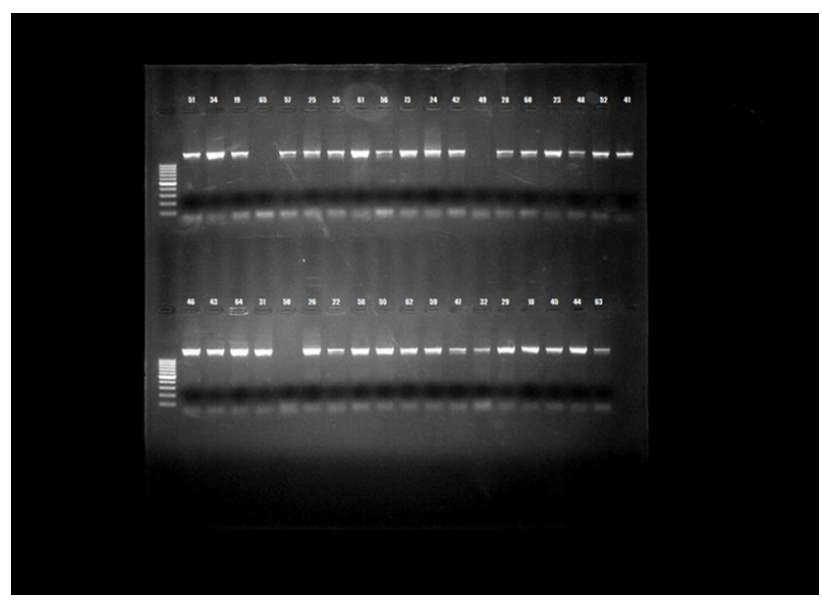

Figure 3. Representative amplification products of isolates (F51, F34, F57, F35, F61, F56, F73, F42, F28, F23, F48, F52, F41, F46, F43, F64, F26, F22, F58, F62, F59, F47, F44, F45, F63 are $S$. parauberis; F19 and F18 L. garvieae; F25 and F24 Vagococcus sp.; F60, F31, F55, F32, F29 are L. lactis subsp.lactis)

Table 2. Antimicrobial susceptibility test of isolates

\begin{tabular}{lllllllllll}
\hline Bacteria & do & en & e & flr & sxt & o & enr & c & v & p \\
\hline F18 & S & R & S & S & S & R & S & R & S & S \\
F19 & S & R & S & S & S & R & S & R & S & S \\
F24 & S & S & R & S & S & S & S & S & S & S \\
F25 & S & S & S & S & S & S & S & S & S & S \\
F22 & S & S & S & S & R & S & S & S & S & S \\
F26 & R & S & S & S & R & I & I & R & S & S \\
F34 & S & S & S & S & S & S & S & S & S & S \\
F42 & S & S & S & S & S & S & S & S & S & S \\
F43 & S & S & S & S & S & S & S & S & S & S \\
F47 & S & S & S & S & S & S & S & S & S & S \\
F48 & S & S & S & S & S & S & S & S & S & S \\
F51 & S & S & S & S & S & S & S & S & S & S \\
F52 & S & S & S & S & S & S & S & S & S & S \\
F57 & S & S & S & S & S & S & S & S & S & S \\
F58 & S & S & S & S & S & S & S & S & S & S \\
F59 & S & S & S & S & S & S & S & S & S & S \\
F60 & S & S & S & S & S & S & S & S & S & S \\
F29 & S & S & S & S & S & S & S & S & S & R \\
F31 & S & S & S & S & S & S & S & S & S & S \\
F32 & S & S & S & S & S & S & S & S & S & S \\
F55 & S & S & S & S & S & S & S & S & S & S \\
\hline
\end{tabular}

(do: doxycycline, en: enoxacin, $e$ : erithromycin, $f$ : florfenicol, sxt: trimethoprim $o$ : oxytetracycline, enr: enrofloxacin, $c$ : chloramphenicol ( $l$ :intermediate sensistive, $s$ :sensitive, $r$ : resistance)).

\section{Discussion}

Initially, main objective of us was detect and isolate lactic acid bacteria with potential probiotic properties. So we isolated bacteria from healthy fish. But from the molecular results also we isolated $S$. parauberis that is a pathogenic bacteria for fish especially in rainbow trout. Streptococcosis is associated with acute and chronic mortality in many aquaculture species (Nho et al. 2009). The considerable diversity of streptococcus bacteria associated with fish may explain the difficulties encountered when identification procedures are based only on phenotypic characteristics. The identification schemes for the causative agents, based on biochemical and antigenic features can barely differentiate these bacterial pathogens from other low virulent gram-positive cocci such as L. lactis. The study has been conducted using conventional 
methods and miniaturized systems and have given variable results. Thus, final identification of the bacteria requires the support of genetic data.

The PCR method can be employed as a supplementary and complementary test for definitive identification of the bacteria cultured from suspected samples. Isolates identified through phenotypic methods did not support the sequence results obtained through 16Sr RNA sequencing. This result indicated that conventional method are not enough or useful in the identification of $S$. parauberis or the other lactic acid bacteria isolates (Domenech et al. 1996; Haines et al. 2013; Park et al. 2013). In some studies, 16Sr RNA sequencing technique was used for identification of $S$. parauberis and lactic acid bacteria (Haines et al. 2013; Pourgholam et al. 2013; Didinen et al. 2014 ). So we can say that 16Sr RNA technique is very powerful for discriminating of lactic acid bacteria and also $S$. parauberis. Also in our study we identified Vagococcus sp isolated by Didinen et al. (2011) from Turkey and L. garvieae isolated by Diler et al. (2002) and L. lactis subsp. lactis.

Antibiotic resistance and sensitivity in lactic acid bacteria vary depending on the strains and the source of isolation (Salminen 1998). Antibiotic susceptibility test results are given in Table 2. Of the samples studied, except F18, F19, F26, F22 and F29 all isolates were sensitive to all antibiotics tested. All $S$. parauberis isolates were sensitive to vancomycin and erythromycin. This result was similar with (Haines et al. 2013; Pitkälä et al. 2008). The highest antibiotic resistance was to enoxacin, oxytetracycline and chloramphenicol.

S. parauberis isolates were obtained from apparently healthy rainbow trout and experimentally injected trout managed to demonstrate symptoms of streptococcosis such as exophtalmus, hemorrhage, erratic swimming, dark skin. Haines et al (2013) report that they isolated $S$. parauberis from healthy stripped bass as we did, but when they infected fish with S.parauberis they failed to demonstrate the signs of streptococcosis. This could be explained as; the fish species we obtained the bacteria may not be susceptible to disease. Also we can think that, in the facility where we obtained pathogen bacteria from healthy fish species may have been an infection caused by $S$. parauberis previously and became a porter.

According to our knowledge this is the first report for isolation and molecular identification of S.parauberis from wild fish and fish farm in Turkey. To date, $S$. parauberis have been isolated from salmon, rainbow trout (Kitao et al. 1981; Eldar et al.1995) mullet, golden shiner, pinfish, eel, sea trout, tilapia sturgeon, red drum (Sciaenops ocellatus), yellowtail (Seriola quinquerodiata) (Kusuda et al. 1991), rabbit fish (Siganus canaliculatus) sea bass (Dicentrarchus labrax); Japanese flounder (Paralichthys olivaceus)], ayu (Plecoglossus altivelis), barramundi (Lateus calcifer) and striped bass (Rahimi and Yadollah 2013). Due to the $S$. parauperis cause major disease in fish species we must alarm the relevant bodies against any disesae outbreaks and we need to take precautions in fish farming Turkey. So this study can be helpful in the prevent of disease outbreaks and may help the researchers in further scientific works.

\section{Acknowledgements}

This study supported by Aegean University Scientific Research Project coded as 2013FEN-050 and Fisheries Research Institute, Egirdir-ISPARTA.

\section{References}

Baeck G.W, Kim J.H, Gomez D.K, Park S.C. 2006. Isolation and characterization of Streptococcus sp. from diseased flounder (Paralichthys olivaceus) in Jeju Island. J Vet Sci. 7(1):53-58. doi:10.4142/jvs.2006.7.1.53

Bondad-Reantaso M.G, Subasinghe R.P, Arthur J.R, Ogawa K, Chinabut S, Adlard R, Tan Z, Shariff M. 2005. Disease and health management in Asian aquaculture. Vet Parasitol. 132(3-4) 249-272. doi:10.1016/j.vetpar.2005.07.005

Didinen B.I, Kubilay A, Diler O, Ekici S, Onuk E.E, Findik A, 2011. First isolation of Vagococcus salmoninarum from cultured rainbow trout (Oncorhynchus mykiss, walbaum) broodstocks in Turkey. Bull Eur Ass Fish Pathol. 31(6): 235-243.

Didinen B.I, Yardımcı B, Onuk E.E, Metin S, Yıldırım P. 2014. Naturally Lactococcus garvieae infection in rainbow trout (Oncorhyncus mykiss Walbaum, 1792): new histopathological observations, phenotypic and molecular identification, Revue Méd Vét. 165(1-2): 12-19.

Diler O, Altun S, Adiloglu A, Kubik A, Isikli B.T. 2002. First occurrence of streptococcosis affecting farmed rainbow trout (Oncorhynchus mykiss) in Turkey. Bull Eur Ass Fish Pathol. 22(1): 21.

Domenech A, Ferna'ndez Garayza'bal J.F, Pascual C, Garcia J.A. Cutuli M.T, Moreno M.A, Collins M.D, Dominguez L. 1996. Streptococcosis in cultured turbot, Scophthalmus maximus (L.), associated with Streptococcus parauberis. J Fish Dis. 19(1): 33-38. doi: 10.1111/j.1365-2761.1996.tb00117.x

Eldar A, Y Bejerano, A Livoff, A Horovitcz, Bercovier H. 1995. Experimental streptococcal meningoencephalitis in cultured fish. Vet Microbiol. 43(1): 33-40. doi:10.1016/0378-1135(94)00052-X

Facklam RR, Elliott JA. 1995. Identification, classification and clinical relevance of catalase-negative, gram-positive cocci, excluding the streptococci and enterococci. Clin Microbiol Rev. 8(4): 479-495. 
FAO. 2016. Tha state of world fisheries and aquaculture, Rome, 200p.

Haines A, T.Gauthier D, E.Nebergall E, D.Cole S, M.Nguyen K, W.Rhodes M, K.Vogelbein W. 2013. First report of Streptococcus parauberis in wild finfish from North America. Vet Microbiol. 166(1-2):270-275 doi:10.1016/j.vetmic.2013.05.002

Hoshina T, Sano T, Morimot K, Jofre J. 1958. A streptococcus pathogenic to fish. J Tokyo Univ Fish. 44: 57-68.

Kesarcodi-Watson A, Kaspar H, Lategan M.L. J, Gibson L. 2008. Probiotics in aquaculture: The need, principles and mechanism of action and screening processes, Aquaculture, 274(1): 1-14. doi:10.1016/j.aquaculture.2007.11.019

Kia RE, Yadollah M. 2013. Detection and 1dentification of different Streptococcosis strains in farmed rainbow trout in Boyerahmad and Dena regions (North South of Iran), World Journal of Fish and Marine Sciences 5(3): 315-321. doi:10.5829/idosi.wjfms.2013.05.03.72123

Kitao T, T Aoki, R Sakoh. 1981. Epizootic caused by betahaemolytic Streptococcus species in cultured freshwater fish. Fish Pathol. 15(3-4): 301-307. doi:10.3147/jsfp.15.301

Kusuda K, Kawai K, Salati F, Banner CR, Fryer JL. 1991. Enterococcus seriolicida sp. nov., a fish pathogen Int. J Syst Bacteriol. 41(3-4): 406-409.

Lämmler Ch, Abdulmawjood A, Danic G, Vaillant S, Weig R. 1998. Differentiation of Streptococcus uberis and Streptococcus parauberis by restriction fragment length polymorphism analysis of the $16 \mathrm{~S}$ ribosomal RNA gene and further studies on serological properties. Med Sci Res. 26, 177- 179.

Liu D. 2000. Rapid mini-preparation of fungal DNA for PCR. Journal of Clinical Microbiology. 38 (1): 471.

Nho LW, Shin GW, Park SB, Jang HB, Cha IS, Ha MA, Kim YR, Park YK, S. Dalvi R, Kang BJ, Joh SJ. 2009. Phenotypic characteristics of Streptococcus iniae and Streptococcus parauberis isolated from olive founder (Paralichthys olivaceus) Fems Microbiol Lett. 293(1): 20-27. doi:10.1111/j.1574-6968.2009.01491.x

Park-Ae M, Mun-Kwon G, Hwang-Jee Y, Jung-Sung H, Kim-Dong W, Jin-Young P, Kim J.S, Na Y.J, Kim M.Y, Kim D.S, Chae S.H, Seo J.S. 2013. Genome Sequence of Streptococcus parauberis Strain KCTC11980, Isolated from Diseased Paralichthys olivaceus, Genome Announc. 1(5):e00780-13. doi:10.1128/genomeA.00780-13

Pitkälä A, Koort J, Björkroth J. 2008. Identification and Antimicrobial Resistance of Streptococcus uberisand Streptococcus parauberis Isolated from bovine milk samples. J. Dairy Sci. 91(10):4075-4081 doi:10.3168/jds.2008-1040

Pourgholam R, Laluei F, Saeedi AA, Taghavi MJ, Safari
R, Zahedi A. 2013. Identification of some streptococcus species isolated from rainbow trout (Oncorhynchus msykiss) in Iran by using molecular method. Journal of Novel Applied Sciences, 2 (S4): 1228-1233.

Romalde JL, Ravelo C, Valdes I. Magarinos B, de la Fuente E, Martin CS, Avendano-Herrera R, Toranzo AE. 2008. Streptococcus phocae, an emerging pathogen for salmonid culture. Vet Microbiol. 130(1-2): 198-207. doi: 10.1016/j.vetmic.2007.12.021

Salminen S. 1998. Demonstration of safety of probiotics. Int J Food Microbiol. 44: 93-106.

Pérez-Sánchez T, Balcázar JL, García Y, Halaihel N, Vendrell D, de Blas I, Merrifield DL, RuizZarzuela I. 2011. Identification and characterization of lactic acid bacteria isolated from rainbow trout, Oncorhynchus mykiss (Walbaum), with inhibitory activity against Lactococcus garvieae. J Fish Dis. 34(7):499-507. doi: 10.1111/j.1365-2761.2011.01260.x

Schleifer, KH. 1986. Gram-positive cocci. In Bergey's Manual of Systematic Bacteriology. Sharpe, M.E. and Holt, J.G. (Eds), The Williams and Wilkins Co., Baltimore, Md. p. 999-1103.

Soto LP. 2010. Molecular Microbial Analysis of Lactobacillus Strains Isolated from the Gut of Calves for Potential Probiotic Use. Vet Med Int. 2010: 1-7. doi:10.4061/2010/274987

Subasinghe R, Soto D, Jia J. 2009. Global aquaculture and its role in sustainable development Rev Aquacult. 1(1): 2-9. doi:10.1111/j.1753-5131.2008.01002.x

Toranzo A.E, Devesa S, Heinen P, Riaza A, Nu'ñ ez S, Barja J.L. 1994. Streptococcosis in cultured turbot caused by an Enterococcus-like bacterium. Bull Eur Assoc Fish Pathol. 14(1): 19- 23.

Toranzo T, Alicia Magarin os Beatriz, L Romalde Jesu' s. 2005. A review of the main bacterial fish diseases in mariculture systems. Aquaculture 246 (1-4): 37 - 61. doi:10.1016/j.aquaculture.2005.01.002

Williams A.M, Collins M.D. 1990. Molecular taxonomic studies on Streptococcus uberis types I and II. Description of Streptococcus parauberis sp. nov. J Appl Bacteriol. 68(5): 485-490. doi:10.1111/j.1365-2672.1990.tb02900.x

Yang W and Li A. 2009. Isolation and characterization of Streptococcus dysgalactiae from diseased Acipenser schrenckii, Aquaculture, 294(1-2): 14-17. doi:10.1016/j.aquaculture.2009.05.018

Zlotkin A, Hershko H, Eldar A. 1998a. Possible transmission of Streptococcus iniae from wild fish to cultured marine fish. Appl. Environ. Microbiol. 64(10): 4065-4067.

Zlotkin A, Eldar A, Ghittino C, Bercovier H. 1998b. Identification of Lactococcus garvieae by PCR. J. Clin. Microbiol. 36(4): 983-985. 